\title{
Amazonian masters in theory and in practice
}

About Luiz Costa's The owners of kinship. Asymmetrical relations in indigenous Amazonia (Hau Books, Chicago, 2017)

Olivier Allard

\section{OpenEdition}

\section{Journals}

Electronic version

URL: https://journals.openedition.org/jsa/16997

DOI: 10.4000/jsa. 16997

ISSN: 1957-7842

Publisher

Société des américanistes

\section{Printed version}

Date of publication: 15 June 2019

Number of pages: $125-141$

ISBN: 978-2-902715-11-4

ISSN: 0037-9174

\section{Electronic reference}

Olivier Allard, "Amazonian masters in theory and in practice", Journal de la Société des américanistes [Online], 105-1 | 2019, Online since 15 June 2019, connection on 02 September 2022. URL: http:// journals.openedition.org/jsa/16997 ; DOI: https://doi.org/10.4000/jsa. 16997 


\title{
Amazonian masters in theory and in practice.
}

\author{
About Luiz Costa's The owners of kinship. \\ Asymmetrical relations in indigenous Amazonia \\ (Hau Books, Chicago, 2017)
}

Olivier AlLARD *

Luiz Costa has offered us an important and fascinating book on the topic of ownership in lowland South America (aka "Amazonia"), rich with ethnographic details, astute interpretations, and bold theorization. While deeply impressed by Costa's work and convinced by many of his arguments, I also found myself disagreeing with as many other interpretations or developments he makes - some of which have to do with the purpose and nature of our work as anthropologists. I want to acknowledge this fact from the beginning, rather than disguise my criticism under polite compliments, for I write this commentary in order to prompt debates about Amazonian relations of mastery, as well as about the type of anthropological knowledge produced in Amazonia.

While Amazonia has long been equated with resolute equality and horizontal relationships, there is a growing body of scholarship on the issue of mastery or ownership (which would translate in French as "maitres," and "maîtrise," in Portuguese as "donos," in Spanish as "dueños," etc.), and more generally on asymmetrical relationships. It is these debates that this book seeks to advance. The recognition of the pervasiveness and cross-cutting nature of those relationships can be traced back to Erikson (1987) on pet-keeping and Menget (1988) on adoption, but we had to wait until the 2000s for works on the question to flourish, with the superb synthesis by Fausto (2008) and the stimulating work on pre-Columbian slavery by Santos-Granero (2009), as well as a number of new ethnographies (listed by Costa, p. 6, n. 2; some are quoted at length by Fausto 2013). Within this discussion largely conducted by closely related anthropologists, Costa's book will certainly appear and remain as a landmark, taking this question as an exclusive point of entry into the ethnography. It is also designed as a trial and assessment of Fausto's model, which Costa subjects to a thorough ethnographic investigation based on his fieldwork with the Kanamari of Southwestern Amazonia in Brazil between 2002 and 2006, with an additional visit in 2015. In Fausto's (1999) original formulation, mastery

* EHESS, Laboratoire d'anthropologie sociale [olivier.allard@ehess.fr]. 
(as it is often translated) or ownership (as Costa prefers) represents a key relationship that bridges conflicting understanding of Amazonian social life: it is the missing link between predation (foregrounded by Viveiros de Castro and others) and commensality (highlighted by Overing and others) ${ }^{1}$ it enables the conversion of affinity into consanguinity through the familiarization of captives (in Fausto's [1999] original formulation), and more generally represents a "cosmological operator" that accounts for the dynamic nature of Amazonian life and the absorption of new events into given patterns (Fausto 2008). Costa confirms Fausto's model, while enriching it as the same time, insofar as he illustrates "how the Kanamari act to ensure that predation becomes feeding and that feeding becomes kinship" (p. 230).

The originality of Costa's contribution lies in the detailed analysis of how predation relates to kinship, following a path that might not be the one expectedpredation becomes more and more present in a text that starts with feeding. Moreover, this is also a very particular take on the topic of mastery or ownership, insofar as Costa explicitly presents his work as the study of a "concept" (p. 223), and therefore takes as a starting point some key Kanamari expressions and words that he discusses at length. The first and most important of these, "-warah," which refers primarily to the owner of something or someone ("X-warah" is "the owner of X"), is generally translated by Costa as "body-owner" (a point I will discuss in due course), and allows a number of possible reciprocal terms (e.g. pet, child, or just a possessive mark). Privileging this key term is probably one reason why, as Costa acknowledges at the beginning of his book (p. 20), he largely describes those asymmetrical relationships from the master's point of view, whereas other ethnographies have explored how they look like from the subordinate's perspective. ${ }^{2}$ This focus on concepts is also in line with the position promoted by Hau, the publisher of the book, which claims as anthropology's specific mission the production of concepts out of ethnography (see Da Col and Graeber 2011, p. viii). While Costa does not explicitly refer to this project, his analysis of Kanamari concepts of ownership, largely drawn from the complex translation of "warah" and its uses, would certainly fit into it. Most of my dissatisfactions with the book relate to this stress on conceptual novelty and the placing of ethnography in its service. As I will discuss below, I am sceptical of Costa's central concept of the "body-owner" and of the lexical and morphological analysis from which it is derived, and I will therefore essentially try to formulate an internal critique.

1. This distinction of various "analytical styles in contemporary studies of Amazonian societies" dates from Viveiros de Castro (1996, p. 188). From the original tripartite division, it has often been reduced to a binary opposition between French-Brazilian alterity and British intimacy.

2. See, for instance, Bonilla (2005) or Walker (2012). 


\section{Feeding animals and spirits}

One of Costa's great insights is to foreground a practice already well documented in Amazonian ethnology, but which he submits to further analysis: pet-keeping. Costa emphasizes its importance among the Kanamari and details its concrete workings. Pet-keeping originates in the feeding of a wild animalusually a youngling whose parents have been killed while hunting -, which its new owner nurtures in order to "familiarize" it. This logic might not be a surprise to readers familiar with the region, but the Kanamari are strikingly articulate about it. As Costa puts it, they are well aware that, at least in this situation: "Feeding is not an act that cancels out a previously existing need (i.e., hunger), but one that instills or perpetuates a need" (p. 26). In creating a need for the feeder, it turns him or her into an owner (although, as Costa will note, ownership can also exist without nurture). Pets, like children, are being "caused to grow" (p. 32), precisely because they are fed, but the crucial difference is that owners try to preserve the juvenile traits of their pets, as if those pets were to remain children forever: they never become autonomous and do not reproduce in captivity. And yet pets age, and as they age they become less dependent and more aggressive, especially towards anyone but their feeder. So what are people to do with them? I found Costa's discussion of this paradox, as well as the various possible responses of the Kanamari, fascinating. Some choose to give or exchange old pets with whites or other Amerindians, knowing that they might be killed and eaten, while others try to cope with them. In one instance some teenagers killed and disposed of a couple of otters that had become hostile to any visitors, in another a woolly monkey was given a separate hammock in a designated place in the household (p. 55-56).

Pet-keeping is an extreme (or maybe pure?) form of ownership, because it is probably the most one-sided: as Costa reminds us throughout the book, using it as a standard against which to compare other forms of ownership, mutuality can never be achieved with pets, since they can never become producers of food nor commensals. This is one instance where the distinction between (unilateral) feeding and (reciprocal) commensality becomes crucial, and I think it should encourage the investigation of other cases where feeding does not imply (and sometimes precludes) commensality, a difference which stems from the concrete way in which food is provided. To give one contrastive example, Jabin (2016, p. 468-476) discusses the feeding of Yuqui slaves who nonetheless never become their masters' relatives (what he calls "heterotrophy"). In spite of this asymmetry, Kanamari pets can in some cases (but certainly not all) be "loved" by their owner, which would imply a reciprocal feeling: Costa mentions the possibility of funerary laments for a deceased pet, and gives the moving example of a man who advises against showing his wife a picture of herself with her late pet woolly monkey, since it would reignite her grief (p. 40). 
Both behaviours are so typical of reactions to the death of (human) relatives in lowland South America that I was struck by their occurrence in this context.

The relationship with shamanic (pet) spirits is very similar to that with (animal) pets - an almost systematic connexion in Amazonia-, but it is also slightly more ambivalent. Indeed, what is familiarized is not a helpless youngling, whose parents have been killed, but a powerful and potentially dangerous being. Feeding is therefore not a means of making them grow, but rather an "educative measure" (p. 51), a way of appeasing them. Among the Kanamari, such spirits would primarily be the "jaguar hearts" of dead shamans (p. 43), which a novice shaman has to capture in order to become fully qualified. Interestingly, this predatory step follows an earlier benevolent one, during which a shaman willingly places a "dyohko" (shamanic substance or spirit) in a young boy's flesh, so that it will "grow inside with him" and later enable him to acquire his own auxiliary spirits (p. 42). To illustrate how those different relations are connected, Costa gives the fascinating example of a shaman who told him how he had familiarized the "jaguar heart" of his late father-in-law, before the pouch where he had stored it was stolen, along with the pet-spirit (p. 44-48)! I was struck by the fact that you could "steal" an auxiliary spirit in such a way, merely by snatching its material container and feeding it properly, since it disproves my earlier assumption that shamanic spirits could only be seduced away (Vienne and Allard 2005, p. 131). Costa uses this narrative to show that the former father-in-law had to be turned into an enemy in order to be subsequently familiarized: it was not possible to familiarize his "heart" directly. However, he had already become a danger to his former kin, and it was therefore necessary to go through this process. And yet, even when it succeeds, the shamanic spirit is kin to the shaman but not to the shaman's own relatives (p. 48): this widespread idea explains the common moral ambivalence of shamans themselves.

The discussion of pets and shamanic spirits also provides a first approximation of the link between feeding and predation. Pets are not eaten by their owner, in the same way that spirits do not prey on those who feed them (p. 53). Indeed, an action often given as a typical example of feeding is for a woman to chew some food and place it in the mouth of her pet (p. 28), precisely what Surrallés (2003, p. 45-46) had described as "anti-predation" in his study of the Jivaroan Candoshi. But concomitantly, both pet-keeping and shamanism show that ownership originates in predation and must also curb it: this is a question that reappears throughout Costa's book and is the focus of its final chapter.

As often as it is compared to shamanism, pet-keeping is contrasted to domestication and the treatment of domesticated animals (or livestock). According to the Kanamari, domesticated animals are "the small animals of the whites" (p. 81), that is to say, animals essentially associated with them, and Costa spells 
out very clearly the scandal, from a Kanamari point of view, of eating what you feed, since it represents a predatory form of kinship (p. 90). But the Kanamari precisely try to circumvent this problem. On the one hand, they do not actually feed chickens and pigs, but rather let them eat by themselves. On the other hand, they raise them for the white inhabitants of the neighbouring town of Atalaia do Norte, who are their real owners (p. 83-85). Kanamari people merely "have" livestock without being their "owners" (p. 83) - a distinction I will return to-, or are said to "act as their caretakers" (p. 85). Costa sees this pattern of raising animals for white people as a transformation of the "aviamento" system, typical of rubber extraction in the area (and known as "habilitación" in most Spanish-speaking Amazonia): when work only takes place as the compensation for (or reimbursement of) goods that have previously been advanced, then "everything that is produced already belongs to others - and will be consumed by others" (p. 95). This leads him to the suggestive idea that it is a way for the Kanamari not only to avoid doing what they would consider scandalous, but also to spare local whites the infamy of engaging in what Kanamari consider immoral behaviour: by raising livestock for white people, they spare the latter having to eat their pets or "children" (p. 206).

\section{Kinship and history in Brazilian Amazonia}

Costa then turns to human children, who stand out against the backdrop of children that never become adults (animal pets), of pets that are kin only to their owner (shamanic spirits), and of children that some people eat (livestock, and specifically chickens owned by white people). Chapter 3, "On the child's blood," constitutes a wonderful discussion of the idea that Amazonians "make kin out of others" (Vilaça 2002). Indeed, the Kanamari stress the otherness of the newborn: a woman told Costa that becoming pregnant was like being "grabbed" by "another" (p. 103), couvade prescriptions and prohibitions are meant to protect not the child but rather its parents and their close relatives (p. 110), and there is an actual fear of the child to be born, which finds a solution in contraception (although, as a vulgar positivist, I was somewhat surprised that Costa described those practices as if the insertion of a shamanic spirit did actually render women barren, p. 104-106). Babies, like enemies, have "new blood," and the couvade is therefore "a metaphorical posthomicide seclusion" rather than the other way around, as most anthropologists have weighted it (p. 119). With respect to kinship, what matters is not birth itself, but rather the baby's first suckle: it establishes the mother-child relationship as a feeding relationship, which is why the mother is said to be the owner (-warah) of her child (p. 121-122). Food is here salient without being said to transform bodily substance and therefore to create a "substantial" bond between people (which 
is also true of blood), so that feeding and commensality must rather be seen as "means of engaging others" (p. 17). ${ }^{3}$

Such an idea might remind us of Gow's (1991) ethnography of the Peruvian Piro (Yine), and Costa conducts a fascinating dialogue with Gow, here as in a few other places, although the affective dimension of relationships seems less central in the Kanamari material. Among the Kanamari as among the Piro, fosterage is foregrounded and glossed as "to cause to grow" (p. 129). This is indeed a very widespread idiom, which I also encountered among the Venezuelan Warao with whom I did fieldwork: they commonly talk of their foster child as he or she "who grew up in my hands," and conversely of a foster parent as he or she "in whose hands so-and-so grew up." Kanamari foster parents are usually older people, to whom a grandchild is entrusted so that they may keep "making themselves body-owners" instead of having a "body-owner," as if it were radically exclusive (p. 133-134). More simply, it could probably be said that fosterage takes place so that older people can keep on caring for someone. However, this seems to be a rather hypothetical deduction made by Costa, and in some other places, people would merely justify fosterage by saying that it is sad to remain alone (e.g. Peluso and Boster 2002, p. 142). What is, however, striking is that, among the Kanamari, a foster mother is called the "owner" of her foster child but never his or her "mother": terms for father and mother apply to only one individual each (the mother being the first woman the child suckled), and are not transferred to foster parents (p. 129, 133). This is rather unusual in the ethnographic record at large. ${ }^{4}$ According to Costa, this is so because there would simply be no foster parents without a birth/suckling mother, and the former therefore never eclipses the latter. He has a very nice way of summing up his argument: "Since every child is an enemy, every birth is an adoption by capture, and every relation of fosterage celebrates the existence of the kinship relations that successfully defused the threat posed by birth-capture" (p. 135).

Kinsfolk, before they can engage in reciprocal relations of love and care, need to have been (unilaterally) fed. If, from a personal point of view, it means having parents, from a collective point of view it means having a chief. Kanamari chiefs, defined as "owners of people," are indeed the precondition of kinship: "[T]here are no settlements without chiefs and no kinship without settlement" (p. 226). This is also why kinsfolk who inhabit the same settlement do not represent "a lot

3. See also Allard (2006, p. 452-454) for a discussion (and a critique) of the role granted to bodily substance in kinship studies, especially in Amazonia.

4. Costa acknowledges that children might call the woman who has fostered them "mother" in address, if not in reference (p. 130), but downplays this fact. It is difficult to ascertain whether the privilege given to reference terms comes from the Kanamari or from Costa; address terms seem to be crucial among the Piro, and it is something that the Warao would systematically emphasize. 
of people," but rather a "cluster" with an intrinsic unity—provided by chiefs-, and in the past they also formed endogamous subgroups. Kanamari chiefs are feeders, insofar as they make commensality possible: in practice, it was at a chief's initiative that a large garden was cleared before being divided into family subplots (and it was therefore his garden), and it was at his house that game was butchered and redistributed (p. 151). Couched in a different idiom, Costa's analysis nonetheless fits well with previous descriptions of the Amazonian chief as a leader or initiator, "he who begins" and whom others follow (Viveiros de Castro 1992, p. 110; Rivière 1984, p. 72-73, see also Costa, p. 73, about "following"). Yet this is essentially what took place in former times. I was a bit surprised that, in spite of noting that we know "only how the Kanamari claim that [subgroups] operated" in the past (p. 178, n. 33), Costa devoted so much effort to the reconstruction of pre-contact social organization and the role of chiefs within it - as if this ideal past was really the stable system that had been destabilized by white Brazilian colonizers and later by state agents. ${ }^{5}$ However, it is true that this system of named endogamous subgroups (which is not unique in Southwestern Amazonia) is striking, and that it enables Costa to introduce some elements that will be useful to his subsequent analyses: according to Kanamari descriptions, the chief used to be the public face of the subgroup, especially on the occasion of rituals that took place between people who were neither enemies nor kin. Drawing on previous discussions, Costa stresses that guests were not fed by their hosts, but rather provided with "antifoods" that made them drunk (p. 164): this meant an avoidance of commensality between hosts and guests, contrary to what has been described for other Amazonians. Hosts and guests were involved in "exchange," that is to say, the barter of various things (p. 167), which is a way of connecting people but also of keeping them distinct ("relations that separate," as Strathern [1988] would say).

I found the analysis of $20^{\text {th }}$ and $21^{\text {st }}$ century changes much more interesting than the reconstruction of an ideal past. Contrary to what happened in other parts of lowland South America, rubber bosses did not replace chiefs nor did they become "owners." When they reached the area, in the 1920s, the high prices of rubber that had marked boom years had already collapsed and bosses did not have the resources to maintain their indigenous clients. This triggered a dispersal of the Kanamari population, who engaged in multiple debt-relationships at the same time, contrary to the centripetal effect that extractive activities had on the Piro, for instance, who were united by coresidence with the same boss

5. Whereas Costa describes the mixing of subgroups as a result of rubber extraction, which took place in the area in the late 1920s (p. 169), he also quotes French missionary Tastevin as saying that the institution of subgroups was "in full disorganization" (p. 138)-and Tastevin lived with the Kanamari between 1909 and 1926, that is to say, before the direct involvement of Kanamari people in rubber extraction. 
(p. 169-172). Conversely, when the first Fundação Nacional do Índio (Funai) representative arrived in 1972, the Brazilian institution in charge of Amerindian people became a hyper-feeder and owner, actually the only owner ever to unite all Kanamari people, therefore creating "a world with a surfeit of kinship" (p. 173). Funai agents did so by generously providing them with food and commodities, and Costa describes how Funai has made local chiefs redundant, by swallowing up the feeding function (p. 181). It is striking that Funai is not identified with particular local employees; rather it serves as a blanket category for all Brazilian institutions, especially those that are powerful and hierarchical, and whose power ultimately originates from Brasilia (p. 178-180).

Finally, Costa attempts to relate historical changes to the Kanamari cosmopolitical order that he mostly infers from mythical narratives. It is also for him a way of going back to the question of predation and feeding that he had tackled earlier, in order to argue that predation is a basic parameter of the world, and that kinship must be extracted from this immanent violence (p. 224). This statement is unlikely to surprise specialists of Amazonia, and Costa underlines how it fits into the classical debate between Viveiros de Castro and Overing, if we may keep using them as metonyms for whole bodies of scholarship (p. 229). Costa more precisely argues that feeding, while being antithetical to predation, also originates in predation from a structural point of view, and not just from the individual perspective of the spirit that is captured or of the pet whose parents have been killed (p. 191). Moreover, feeding, while being a form of protection, also exposes the fed to predation (p. 208). Costa substantiates these claims by telling us that, according to mythic narratives, jaguars were originally the owners of everything, and yet they did not feed what they owned-they merely controlled it, and sometimes fed on it. They were made to relinquish this ownership, but more importantly their corpse, as they died, became a source of food that attracted the animals they used to control (p. 190-193). It shows very clearly that the owner was what unified or concentrated a population: as their owner dies, fish disperse and animals become distinct, and only gather again occasionally when they feed on their former master's corpse. Yet does becoming itself food turn the jaguar into a feeder? It seemed to me that Costa is over-interpreting his data with such a statement (p. 192), so as to phrase all relations exclusively in terms of feeding and ownership. ${ }^{6}$ It is actually

6. The idea of the jaguar as feeder reappears in his analysis of the "jaguar ritual": "The Jaguar, magically captured by the Kanamari and made drunk from the beer, thus transforms game into easy prey during the ritual, replicating the same transformation that it achieves in the myths of the Master of Fish and Master of Game" (p. 219). However, contrary to what is stated in the last part of the quote, I am strongly convinced that feeding humans with its pets is not the same as becoming food for its pets (even when it is rephrased as feeding them with its own corpse). Moreover, Costa states on several occasion that fish originally constituted the body of (or "were the body parts of") the Master of Fish (e.g. p. 191, p. 193; 
concentration, which might be occasioned by feeding opportunities, which exposes people and animals to predation, and dispersal is the usual response to attacks (p. 208). This is a rather common pattern across the world, and it is also interesting to note that it could fit into a completely different theoretical framework (e.g. Scott 2009).

\section{Concepts and practices}

I have been forced to leave out many interesting details and insightful interpretations, but readers who know the work of Luiz Costa will also have noted that I have barely mentioned a question that is rather prominent in his book-the concept of "warah" and its semantic range, and what can be inferred from it. I have largely ignored it until now for two reasons. First, I wanted to show that I consider it to be in fact largely irrelevant to many very convincing arguments advanced by Costa, which could therefore be introduced without much reference to the concept. Second, I would like to articulate in a synthetic way my reservations and disagreements with Costa, which concern both the type of data he foregrounds and the kind of knowledge he wants to produce with it. In a word, I think that Costa gives too much importance to semantic distinctions (as if thought and language were strictly equivalent), sometimes relies on dubious etymologies or draws very hypothetical conclusions from the analysis of linguistic constructions, and that it leads him (in spite of some of his claims to the contrary) to portray "ownership" (or asymmetrical relations) in an overly rigid and static way - as if it were a fixed condition rather than a contextual relation and a matter of practice.

Let us go back to what is a cornerstone of Costa's analysis: "-warah," as I mentioned, can essentially be translated as the owner in relation to what is owned, the torso in relation to limbs or extremities, the trunk of a tree in relation to its branches or seeds, the main course of a river in relation to its tributaries, etc., and it is always preceded by what is owned or subordinate (" $X$-warah" meaning "owner of X") (p. 60-64). Costa has chosen to translate it as "bodyowner" in order to draw attention to the fact that it has no transparent translation into English or other European languages. This choice was also influenced by a crucial misunderstanding with which he opens the book: while trying to ask "how were the bodies of long-ago chiefs?," he fails to find an understandable translation and discovers that both "bodies" and "chiefs" are translated by the same word (-warah) when his interlocutor tells him in Portuguese that: "our body is our owner and our chief" (p. 1-2). This is indeed a remarkable fact, yet after reading the whole book I felt that the lapidary remark of Costa's informant

2010, p. 185), but it never appears explicitly in his translation of the myth, according to which the jaguar "gathers" or "hoarded" the fish (p. 191-192). 
was intended to solve a problem of vocabulary rather than as a comment on the bodily and political order of things. The translation of "-warah" as "bodyowner" in fact did not strike me as felicitous, first because the term of "body" carries some ambiguity, and second because the choice of a stable composite translation can be misleading.

Rendering some of the semantic range of "-warah" as "body" is problematic because the latter has connotations of individuality and wholeness in European languages, whereas the former is essentially a relational concept. In Kanamari, explains Costa, 'the 'body' is only referred to as '-warah' when it expresses a relation of dependence": it designates "the torso in relation to its extremities," or "the body as a whole (i.e., trunk, limbs, head, etc.) when conceptualized in relation to other bodies that are derived and/or dependent on it" (p. 62-63). This quote may imply an evolution of Costa's interpretation of his data, since he had, in an earlier publication, given examples of a much more "individual" meaning of "-warah" as "body" ( "wiri-warah" being, for instance, translated as "the living body of any peccary", or "Poroya-warah" as "Poroya's body", Costa 2010, p. 171-172), whereas I have not noticed similar examples in his book (although it seems to be the case when people are ill and when the soul risks becoming separated from the body, p. 74). He could perhaps have better conveyed his point by talking of the "trunk-owner," insofar as "trunk" implicitly always implies a contrast with the branches (of a tree) or limbs (of a body).

However, I think that such neologisms are unnecessary. It is obviously crucial to pay close attention to language, but Costa risks falling into a kind of lexical and morphological fetishism, which induces him to infer patterns of thought directly from the analysis of language. To stick to "-warah," I am convinced that, with the evidence he provides, it is impossible to claim that: "'body,' 'owner,' and 'chief' are imperfect glosses for what, in the Kanamari language, is one concept" (p. 2, see also Costa 2010, p. 172). In fact it is perfectly possible to translate the word according to the context: "Poroya-warah" may refer to the "owner" of Poroya (e.g. the foster mother who feeds him, if he is a child), or maybe to Poroya's body (if we follow Costa's earlier article). In a realistic linguistic situation in which complete utterances are made in context, it would be clear whether one is referring to an owner or to a body, which is why I believe it is meaningless to translate the word as "body-owner" in both cases. What Costa does is almost comparable to translating the English "chair" into French as "président-chaise" (or in Portuguese as "presidente-cadeira"), in order to stress that in some contexts "chair" can refer to a piece of furniture and in others to a person. We could play the same game with "head" referring both to a body part and to a hierarchical position. There is obviously a link between both uses, and it might be interesting to discuss its cultural implications, but it precisely requires plenty of evidence (especially of a diachronic nature) and a careful 
discussion. I would have been more persuaded by the more modest claim that "-warah" stands for relations that are homologous but not strictly identical.

The consequences of Costa's assumption are sometimes benign and sometimes the source of important shifts in meaning. I fear that the latter is the case when he articulates the cosmological underpinnings of regional organization. Costa draws a contrast between relations across the Juruá River-between the Kulina and the Kanamari, who are equivalent types of people - and relations along the Juruá - the "Dyapa", upriver, are pure enemies, and white people, downriver, are partners in "calculated exchange" (p. 208-209). While convinced by this picture, I did not agree with all the steps of his argument. In myth, Kanamari and Kulina both originate from the seeds of a tree, whereas the Dyapa come from its trunk. Yet, from the fact that the trunk is "-warah" in relation to the seeds, is Costa right to conclude that the Dyapa are the "body-owners" (-warah) of the Kanamari? The Kanamari and Kulina may originate from seeds according to myth, but they are not, by themselves, seeds. The shift from a botanical to a socio-political relation happens surreptitiously between p. 198 and p. 207, without receiving any further justification than this lexical equivalence.

As Costa draws direct conclusions from linguistic features, he struggles to account for some seemingly anomalous elements. This especially clouds his discussion of the distinction between ownership and possession, which is a reformulation of the classic contrast between legal rights and physical control. ${ }^{7}$ In Costa's words: “'Ownership' designates a constitutive relation, one in which both the (body-)owner and that which is owned are defined via the relation. They do not exist as such outside of it. 'Possession' designates a contingent relation, one in which the possessor and the possessee exist independently of the relation. It is extrinsic to them" (p. 76). To give a very simple example of my own, having a child is what makes me a parent, and I cannot really sever this relationship, at least not in the way I can give away an object or sell a chicken. Moreover, ownership is a source of "magnification" of the person (to follow an idiom used both by Fausto [2008] and Taylor [2009]), since the owner is enriched by such relations. This distinction is pivotal, and enables Costa to highlight very important differences in the way people relate to other entities (whether people, animals, things, etc.). For instance, as I have already mentioned, the Kanamari "own" their pets but merely "possess" livestock; and they may "possess" (or "have") sugar, but the "owners of sugar" are the shopkeepers (p. 79, n. 18). ${ }^{8}$

7. This is why property is often said to be a relation between persons with regard to things rather than a direct relation between persons and things, as possession (a direct control over something) would be.

8. My examples also point to two slightly different acceptations of the word, the latter more categorical (shopkeepers in general are the owners of sugar in general), implying a general 
My problem is with Costa's attempt to deduce this distinction from the linguistic constructions for alienable and inalienable possession. He foregrounds this distinction (p. 65sq), even though it seems to fit his data very imperfectly. For instance, while characterizing inalienable possessions as a "condition for being a magnified person", he acknowledges that body parts are "grammatically inalienable possessions" (and "even inanimate things inalienably possess parts of themselves") whereas "alienable possessive constructs" apply to shamanic spirits and ritual songs (p. 67-69). However, most Amazonian anthropologists would consider that the latter are much more important than the former in processes of magnification. Similarly, having claimed that "-warah" is "one concept," Costa is at pains to account for some heterogeneous uses of the word - and one may question whether it is the same word at all and not mere homophony. While "-warah" designates primarily an owner in relation to what is owned, "warah" can also be used as a verb meaning "to have" in general (as possession rather than ownership, p. 75-77), and "warah" is a noun that refers to Western merchandise (which Kanamari people "possess" rather than “own," p. 78). ${ }^{9}$ The explanations offered by Costa are often tortuous. Even more crucially, I didn't feel that it was the most relevant question he could ask of his ethnographic material. I was impressed by his analysis of how the Kanamari deal with livestock in comparison to pets and how this shapes their relation with neighbouring white people, but did not particularly care that they used the same word (or a word sounding similarly) for a constitutive relation of ownership and a type of merchandise that can merely be possessed. It might be worthy of investigation, but it does not always provide a decisive key of interpretation, especially when our knowledge of the language is still in progress. ${ }^{10}$

association, and the former more singular (so-and-so is the owner of this individual pet), implying an interpersonal relation. Both meanings could be included under what Benveniste calls "belonging" (appartenance) in contrast to "possession" (1966 [1960], p. 196-197), in his very careful study of their linguistic expression across a range of languages, whereas "ownership" steers the translation towards the more interpersonal meaning of the term.

9. At least Costa believed his informants when they told him that "wara" (to be born) was a completely different word, but he could not resist the urge to provide a hypothetical etymology linking it to "-warah" (p. 105, n. 4)! Those are different acceptations that he had downplayed in his 2010 article.

10. Questions of vocabulary orient Costa's research on other occasions, for instance when he asks: "Why are subgroups named using a word that designates an enemy of all of them?" (p. 197). "X-dyapa" is the structure of the names of subgroups (with X a particular name) and "Dyapa" refers to the enemies of the Kanamari. On several occasions, without being a linguist and therefore claiming any competence to judge, I was not particularly convinced by Costa's etymologies - but I did not find them necessary to his argument either. See, for instance, his etymology for "to feed" as "to cause need" (p. 25-26). 
This tendency sometimes gives The owners of kinship the appearance of a phrasebook compiling typical sentences about ownership and possession. ${ }^{11}$ We hardly ever know in what context people utter such or such a sentence, to whom, with what intention and what effect, and it often seems that Costa draws on very general discussions he had with his informants. It comes as a pleasant surprise when he provides a detailed story or an account of naturally occurring dialogues - and there is such material in his book, for there is no doubt that he has conducted fruitful fieldwork. Nonetheless, it is as if he had intentionally thinned down his data in order to build a philosophy out of vocabulary.

As a consequence, Costa often ends up producing what I almost consider to be a "jural" concept of ownership, in spite of his claims to the contrary. $\mathrm{He}$ writes, for instance, that "having a body-owner makes one a person, being a body-owner makes one a magnified person" (p. 70, see p. 134 and p. 223 for similar statements), since "having a body-owner" means having been fed and having relatives, while "being a body-owner" means having dependants. By formulating the question in such a general and abstract way, he describes ownership as if it defined objective conditions and rigid statuses according to cultural laws, even if those laws remain implicit until an anthropologist spells them out. But this view seems to be contradicted by his own remarks. First, he has stressed on several occasions that ownership is essentially a relational concept. It is probably possible to ask with respect to a pet a general question such as: "has it an owner?," for instance to distinguish it from an animal that would belong to "the community" (p. 41), or maybe about a shamanic spirit, but I doubt it makes sense to formulate similar questions about a child (who is fed) or an adult (who lives in a settlement led by a chief). Moreover, it is probably impossible to formulate an abstract question such as "is he an owner?" Here, in a sense, Costa should have paid more attention to appropriate uses of the word, and I think it would have shown that it is always a matter of owning particular entities - whether people, animals, or spirits.

Second, Costa also notes that "father and mother are called-warah contextually, in light of certain events" (p. 122), or that "[r] eferences to the subgroup chief depend on contextual cues" (p. 144). One could agree that he had to leave out some contextual variations in order to make the concept intelligible, but I believe that this actually distorts the concept — or rather his depiction of "asymmetrical relations." Costa tells us very little about actual situations of interlocution and merely notes, for instance, that adults engage in reciprocal relationships, "which elide the earlier asymmetrical bonds of dependency" (p. 123). It would be

11. A similar comment could be made on the first sections of Brightman's article on property relations in Guianese Amazonia, although he recognizes that "the relationship between language and thought is problematic, and that between language and society is no less so" (2010, p. 141). 
interesting to know more about those contextual variations, in order to establish whether they concern only lexical choices or whether it is the relation that is eclipsed or obviated in some situations - even more so since there are always multiple relations of ownership that overlap. It is probable (and in line with Costa's analyses) that such variability affects children and followers more than pets and shamanic spirits: if highlighting a pervasive "relational schema" is a good way of showing that life is not partitioned in given spheres or domains, it might also downplay differences between actual instantiations of the schema. This question is crucial when it comes to the ownership of people, and Costa, for instance, says that: "Parents are owners of the children they feed" (p. 15), without ever describing what this ownership entails in terms of claims or rights. It is possible to express the same concern regarding other works on the topic. Brightman, for instance, states that "Trio and Wayana human persons [...] constitute one form of property" (2010, p. 152), challenging McCallum's (2001) claim that relations between parents and children are not comparable to relations between persons and things. But it is not very clear whether he refers to the Akuriyo who were kept in dependence by some Trio and Wayana, to the chief who exercises "a form of 'ownership' or 'mastery' over the villagers" (ibid., p. 148), or to kinship. Challenging the (Western) opposition of subject and object should not automatically lead to the assumption that all beings constitute "property" in the same way, and some lexical equivalence is not enough to say that children are the property of their parents. It would require a study of the control that the latter may have (or not) over the former's labour, sexuality, and reproductive capacities, mobility, etc., or what Brightman, Fausto, and Grotti (2016, p. 19) formulate as the "claims" that people have on others. ${ }^{12}$

Costa is well aware that there are important variations in ownership, yet while he tries to incorporate them in his analysis of the concept (they add "semantic density," p. 52), he is not very interested in how they work out in practice. He could probably argue that my alternative formulations are already present in his work, but that he adopted another focus. Yet I would precisely like to question his general orientation or purpose. Costa wants to elucidate an Amerindian concept, as stated in his introduction, and does so through a study of native language — and of local terms in particular. ${ }^{13}$ Obviously, we can argue that this is integral to the anthropological project of understanding others in their own terms, and Costa specifically quotes Evans-Pritchard about the importance of

12. In this recent paper, Brightman, Fausto, and Grotti retain the aim of challenging the dichotomy between persons and things, but want to study "rights in things, persons, and so forth" in general - what they refer to as "ownership" (rather than property) - and they stress that such rights are often "convoluted" (2016, p. 6, 20).

13. In his earlier article, Costa offers a definition of "-warah" and adds: "The remainder of the article will be a demonstration of this definition" (2010, p. 172). 
determining "the meanings of a few key words" (Evans-Pritchard 1962, p. 80, quoted p. 2). I have reservations about Costa's interpretation of this quote. EvansPritchard defines this as "the most difficult task in anthropological fieldwork," upon which "the success of the whole investigation depends" (ibid.), yet he never dissociated this concern with translation from a study of practices, of life as something that is (and can only be) enacted rather than merely thought and imagined. Conversely, Costa describes and analyses Kanamari concepts almost as if they existed by themselves, probably because they provide him with the original contribution he aims to make to the academic community, and he seems to give detailed examples only as illustration. Similar debates have already taken place on many occasion - for instance with Lévi-Strauss's (1950, p. XLVI) discussion of native and anthropological concepts or with Bourdieu's (2000 [1972]) discussion of theoretical and practical activity-, and I fear that our doom is to replay such discussions forever. Yet it may also be a blessing for anthropology to keep on welcoming diverse and sometimes opposed tendencies, and Costa's book certainly has the great merit of providing innovative interpretations that will fuel current debates about native Amazonia.

\section{References cited}

Allard Olivier

2006 “La parenté en substance. La Critique de Schneider et ses effets," L'Homme, 177-178, p. 437-466.

BENVENISTE Emile

1966 [1960] “'Être' et 'avoir' dans leurs fonctions linguistiques," Problèmes de linguistique générale, Gallimard, Paris.

Bonilla Oiara

2005 "O bom patrão e o inimigo voraz: predação e comércio na cosmologia paumari," Mana, 11 (1), p. 41-66.

Bourdieu Pierre

2000 [1972] Esquisse d'une théorie de la pratique, précédé de trois études d'ethnologie kabyle, Éditions du Seuil, Paris.

BRightman Marc

2010 "Creativity and control: property in Guianese Amazonia," Journal de la Société des américanistes, 96 (1), p. 135-167.

Brightman Marc, Carlos Fausto, and Vanessa Grotti

2016 "Introduction. Altering ownership in Amazonia," in Marc Brightman, Carlos Fausto, and Vanessa Grotti (eds.), Ownership and nurture. Studies in Native Amazonian property relations, Berghahn Books, New York, p. 1-25.

Costa Luiz

2010 "The Kanamari body-owner. Predation and feeding in Western Amazonia," Journal de la Société des américanistes, 96 (1), p. 169-192.

2017 The owners of kinship: asymmetrical relationships in indigenous Amazonia, Hau Books, Chicago. 
DA Col Giovanni, and David Graeber

2011 "The return of ethnographic theory," Hau. Journal of Ethnographic Theory, 1 (1), p. VI-XXXV.

ERIKSON Philippe

1987 “De l'apprivoisement à l'approvisionnement : chasse, alliance et familiarisation en Amazonie amérindienne," Techniques et culture, 9, p. 105-140 [English version: "The social significance of pet-keeping among Amazonian Indians", in Paul Podberseck and James Serpell (eds.), Companion animals and us, Cambridge University Press, Cambridge, 2000, p. 7-26].

EvANS-Pritchard Edward-Evan

1962 Social anthropology and other essays, The Free Press, New York.

Fausto Carlos

1999 "Of enemies and pets: warfare and shamanism in Amazonia," American Ethnologist, 26 (4), p. 933-956.

2008 "Donos demais: maestria e domínio na Amazônia," Mana, 14 (2), p. 329-366.

2013 "Feeding and being fed: reply to Walker," Journal of the Royal Anthropological Institute, 19 (1), p. 170-178.

Gow Peter

1991 Of mixed blood. Kinship and history in Peruvian Amazonia, Clarendon Press, Oxford.

JABIN David

2016 "Le service éternel. Ethnographie d'un esclavage amérindien (Yuqui, Amazonie bolivienne)," Ph.D. dissertation, Social Anthropology, université Paris Ouest Nanterre, Nanterre.

LÉvi-Strauss Claude

1950 “Introduction à l'œuvre de Marcel Mauss," in Marcel Mauss, Sociologie et anthropologie, PUF, Paris, p. IX-LII.

McCallum Cecilia

2001 Gender and sociality in Amazonia. How real people are made, Berg, London. Menget Patrick

1988 "Note sur l'adoption chez les Txicáo du Brésil central," Anthropologie et Sociétés, 12 (2), p. 63-72.

Peluso Daniela, and James S. Boster

2002 "Partible parentage and social networks among the Ese Eja," in Stephen Beckerman and Paul Valentine (eds.), Cultures of multiple fathers. The theory and practice of partible paternity in lowland South America, University Press of Florida, Gainesville, p. 137-159.

RIVIÈRE Peter

1984 Individual and society in Guiana. A comparative study of Amerindian social organization, Cambridge University Press, Cambridge.

SAntos-Granero Fernando

2009 Vital enemies. Slavery, predation, and the Amerindian political economy of life, University of Texas Press, Austin. 
ScotT James C.

2009 The art of not being governed. An anarchist history of upland Southeast Asia, Yale University Press, New Haven.

STRATHERn Marilyn

1988 The gender of the gift. Problems with women and problems with society in Melanesia, University of California Press, Berkeley.

SURRALlÉs Alexandre

2003 Au cœur du sens. Perception, affectivité, action chez les Candoshi, CNRS Éditions/Éditions de la Maison des Sciences de l'Homme, Paris.

TAYLOR Anne-Christine

2009 "Le corps de l'âme et ses états. Être et mourir en Amazonie," Terrain, 52, p. 38-49.

VienNe Emmanuel de, and Olivier Allard

2005 "Pour une poignée de dollars ? Transmission et patrimonalisation de la culture chez les Trumai du Brésil central," Cahiers des Amériques latines, 48-49, p. 127-45.

VILAÇA Aparecida

2002 "Making kin out of others in Amazonia," Journal of the Royal Anthropological Institute, 8 (2), p. 347-365.

Viveiros de Castro Eduardo

1992 From the enemy's point of view. Humanity and divinity in an Amazonian society, The University of Chicago Press, Chicago.

1996 "Images of nature and society in Amazonian ethnology," Annual Review of Anthropology, 25, p. 179-200.

WALKER Harry

2012 "Demonic trade: debt, materiality, and agency in Amazonia," Journal of the Royal Anthropological Institute, 18 (1), p. 140-159. 
